\title{
Rendering Learning Approach With Islamic Religious Education Subjects and Students Accounting XI Relationship with Management and Business
}

\author{
Amirudin $^{1}$, Iqbal Amar Muzaki ${ }^{2}$ \\ \{amirudin@staff.unsika.ac.id ${ }^{1}$, iqbalamar.muzaki@fai.unsika.ac.id ${ }^{2}$ \} \\ Faculty of Islamic Religion University of Singaperbangsa Karawang Karawang, West Java, Indonesia ${ }^{1,2}$
}

\begin{abstract}
This study aims to to analyze the influence of the approach of learning to promote disorder to rendering on the subjects of the islamic religion education and accounting a class of $\mathrm{XI}$ and the remaining buses of accounting well as those from vocational KandanghaurIndramayu.The technique of an analyzer will be used in this research was linear regression of multiple in order to obtain a whole description on the relationship between variables reaches as high as one with dependent variable for which a other The research results show that in partial and simultaneous subjects islamic education and accounting have leverage to the approach of learning rendering. In the research indicated that the approach rendering is very important in islamic education and it will have provided a positive contribution also on the subjects of accounting where of reality practice accounting requires can be doing accurately and transparent.
\end{abstract}

Keywords: approach learning, rendering, islamic education and accounting

\section{Introduction}

The act of the national education system no 20 of 2003 education is a conscious effort planned manner to realize the atmosphere of learning and the teaching process so that member primary school students actively develop the potential of each himself to have the power of religious spiritual, self-control, personality, intelligence, the remembrance of the noble, as well as the skills required himself, the community a nation and a country.

The quality of education can be achieved if the teaching process in the effectively, nor shall taken place in a smoothly directed and in accordance with the purpose of learning. Those to whom we have are closely connected to learning how to build the interaction that both between two components and that is teachers who were the primary school students. The interaction that good can be described with a state in which the teacher could make the primary school students learn by easy and impelled by his own volition to study what is in the curriculum as their needs.Therefore, every learning especially learning Islamic should be trying to outline the values that is contained in the curriculum and connecting it with the fact that were around the primary school students.At this time, learning education in Indonesia there are still many centered on teachers (teacher center).

One of the approaches during is centered to their students is the approach rendering (rendering approach).Rendering approach in their experiences in the it includes components; 
observing, ask, to think, trying to/created, presenting/communicate (the ministry of education and culture, 2013 in asihwulandari, 2015: 3) .

In economic application that kind of apply to SMK is to bridge or as the media to develop the potential of each himself to have the power of religious spiritual, self-control, personality, intelligence, the remembrance of the noble, economic and skills this program is the field of accounting, it is it is hoped students primary school students understand noted, and grouping report from financial transactions in a transparent and accountable

\section{Review the theory}

Approaches were used for the rendering is the concept of accommodate, inspire, confirm the truth of the melatari thoughts on how to learning to promote disorder to applied, was the way to establish their knowledge and skills reflect or have they taken that could support the activity of creative in for innovation to come alive or work left in me[1, p. 3].Approach rendering (scientific approach).Rendering approach is an approach learning who directs school tuition actively the concept, law or principle through the scientific packed in core activities learning which includes activities observe (observing), one another (questioning), trying to/collect the data (experimenting), think/associating, and communicate (communicating)[2, $\mathrm{p}$. 34].Several models, strategy, or method of learning be applied teachers by integrating elements approach rendering in learning.The model in accordance with approach learning rendering including learning based of a problem (the problem based learning) and learning based projects (project based learning)[3, p. 76].Kind described Sani[3],the problem based learning is defined as learning who makes students learn to through a real settlement effort problems the world.

Based on two that definition can be expressed the equation of big problem and hard to based learning and project based learning is that related to how studies the concept of based on the problems and apply the ability of resolve problems that arise to reality. While the difference between them is the existence of the product which is must be made and displayed of students in project of birth certificate program based learning [3].The use of two the model was to use it in turns out of school in droves compatible with the context the material of which be further explored can create the learning environment aimed at peaceful and steady and there you shall remain not only to his province council and the knowledge alone but also can touch the aspect of the measures and the behaviour, and skill because the students trained work together, communicate, resolving problems the schools, and makes decisions.

The experimental work on this, developed learning model the problem of fee-based learning and project learning system heavily used the rendering learning.The trial will be done in the direction of the SMK grader student of accounting. The selection of the subject of the trial because vocational high school graduates are requested to not only understanding the concept of but also the practice of so vocational high school students need to trained understand to solve the problem the real world that is, make a product, and displays them.

Kind of classroom is a pattern that describe the order learning activities and the creation of learning environment from start to finish the lessons that presented by teacher was in it the determination of the approach, strategy a method that in accordance with matter that are to be delivered, the purpose of learning, and the level of ability primary school students so that enables the student to accomplish a purpose learn certain.

Basically, in the development of kind of classroom there are basic elements involved closely[4, p. 16] expressing five basic elements in the model of learning such as amp;1) 
syntax, 2) social system, 3) principles stage of reaction, 4) support system, 5) instructional and nurturanteffect.Hence, evaluation kind of classroom said to have been better to minimize have met five. Evaluations element of the results of the development of kind of classroom also covered the assessment of matter and the quality of the teaching material in the form of a book of directions teachers and students book that will be used for the implementation of the problem of fee-based kind of classroom learning and project based learning .The problem of feebased learning is a kind of classroom who directs students to think critically in resolving problems the the real world to obtain the concept of matter learned by the teacher role that acts as a facilitator in their in their experiences While project based learning

Second kind of classroom went through several stages has had of learning which he different from what is mentioned.Big problem and hard to based learning according to Abrahamet.,al., (2000) in [5, p. 98] having five phases of promised to supply 1) held in school orientation at issue, 2) organize the student to study, 3) from before them and behind a news conference the investigation individual as well as groups, 4) develop and provides the results of the the work of, 5) look to analyse and in which the process of the solution of a problem .While project of birth certificate program based learning according to the GeorgeLucasEducationalFoundation (2005) having six phases of and among the companies were 1) the determination of the basic question of, 2) made project plans modes of design, 3) they checked schedules, 4) monitor students and progress is being made in to invest in a project, 5) appraise the outcome of, 6) is the need of evaluation those experiences within those years.An assessment at big problem and hard to based learning and project based learning covered three aspects namely cognitive aspects, affective, and psychomotor[6, p. 10]

Learning outcomes those to whom we have implied in the goal of teaching and learning outcomes behavior expected owned after students through the teaching and learning process.For example students having inability provide an annual report, read the report and informs financial to have a better financial report, students be discipline and confident and others.

\section{Accounting}

Accounting is a system information that produces financial information to parties concerned about economic activities and conditions an organization.According to soemarsoamerican accounting association (2015: 13) define that involves the identify accounting, measuring, and reported economic information, to allow a view and decisions clear and expressly for those who used the information.According to. That accounting defined as art how noted, grouping, summarizing and reported transactions (of events) a business[7, p. 4].Accounting is the process of recording, calculating, identifying, measuring and collecting financial information in the form of financial statements that are used for decision making[8, p. 2]. Accounting is divided into several types, including financial accounting and management accounting. Financial accounting is accounting that is structured to produceinformation in the form of financial statements intended forinternal parties and external parties or parties outside the company such asgovernment,investors, creditors, etc., the financial statementsamong themincludes a balance sheet, income statement, change reportcapital, cash flow and notes to financial statements[8]. While management accounting is the financial statements prepared forproduce information that is useful for internal parties or 
companymanagementwhich is used for decision making, that informationcan be policies that are not published forexternal parties[8].

\section{Research Methodology}

The method will be used for obtaining the results of research consistent with the objectives of research, then required the method of analysis the proper data. The method of analysis that used to research this is regression analysis linear multiple to be used to test hypotheses.

$$
\mathbf{Y}=\boldsymbol{a}+\boldsymbol{\beta}_{1} \mathbf{X}_{1}+\boldsymbol{\beta}_{2} \mathbf{X}_{2}+\mathbf{e}
$$

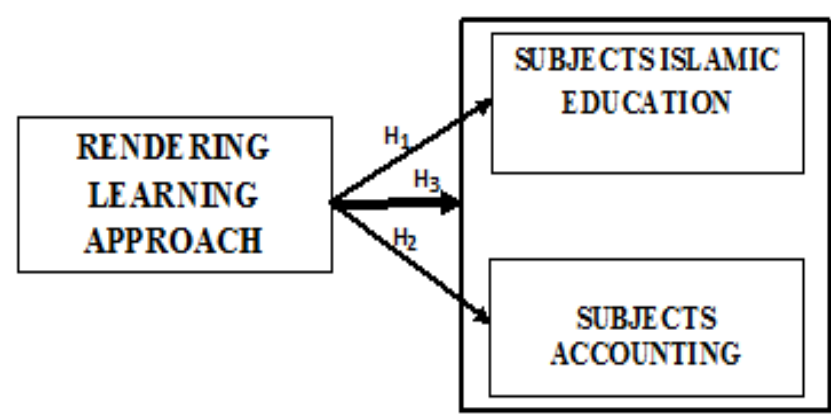

Fig. 1. Model the Framework of Conception

Through observation, interview, such documentation and.In the following analysis of the results of the use writers watchful such guidelines likert scale with 5 (five) alternative answers,

\section{Results and The Discussion}

Table 1 . The results of the test and been approved the Regression and $t$ $\$$

Coefficients

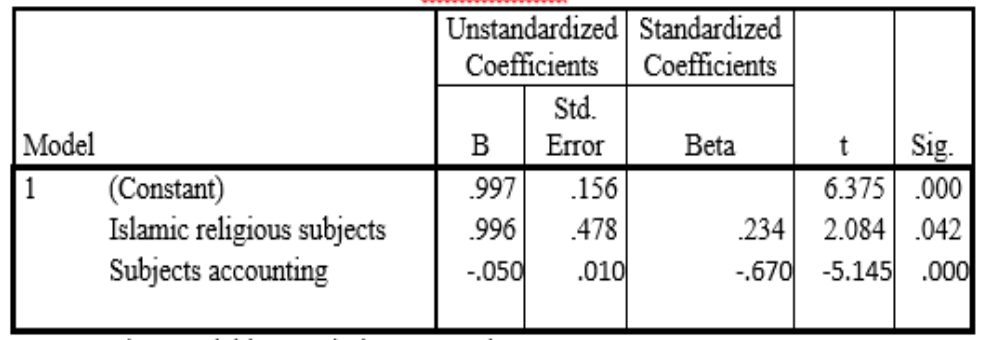

a. Dependent Variable: Rendering approach

Sources: Data processed 
Table 2. Test Results the Coefficients Determination Model Summary

\begin{tabular}{|l|l|r|r|r|}
\hline Model & R & R Square & Adjusted R Square & $\begin{array}{c}\text { Std. Error of the } \\
\text { Estimate }\end{array}$ \\
\hline 1 &, $803^{\mathrm{a}}$ &, 645 &, 629 & 2,67635 \\
\hline
\end{tabular}

a. Predictors: (Constant), Islamic religious subjects, Subjects accounting

Sources: Data processed

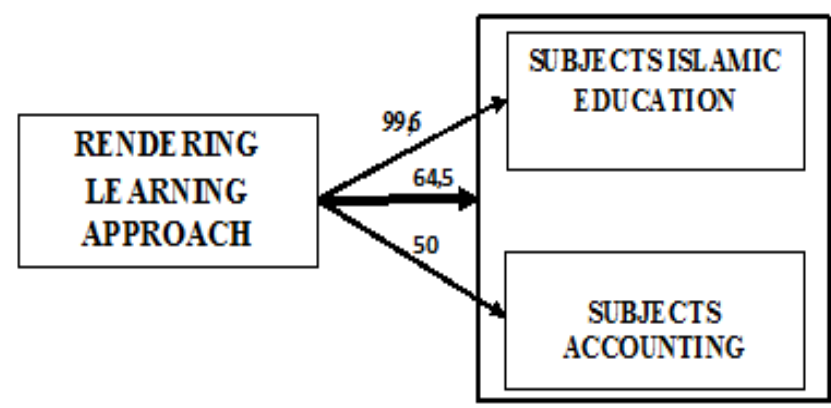

Fig.2. Regression testing shows and Coefficients of Determination

Table 3. Test Results the Significations and $F$

\begin{tabular}{|ll|r|r|r|r|r|}
\hline \multicolumn{1}{|c|}{ ANOVA $^{\mathrm{a}}$} \\
Model & $\begin{array}{c}\text { Sum of } \\
\text { Square } \\
\mathrm{S}\end{array}$ & $\mathrm{df}$ & $\begin{array}{c}\text { Mean } \\
\text { Square }\end{array}$ & $\mathrm{F}$ & Sig. \\
\hline 1 & & .298 & 6 & .050 & 11.198 & $.000^{\mathrm{b}}$ \\
& Regression & .235 & 53 & .004 & & \\
& Residual & .533 & 59 & & & \\
& Total & & &
\end{tabular}

a. Dependent Variable: Rendering approach

b. Predictors: (Constant), Islamic religious subjects, Subjects accounting

Sources: Data processed 


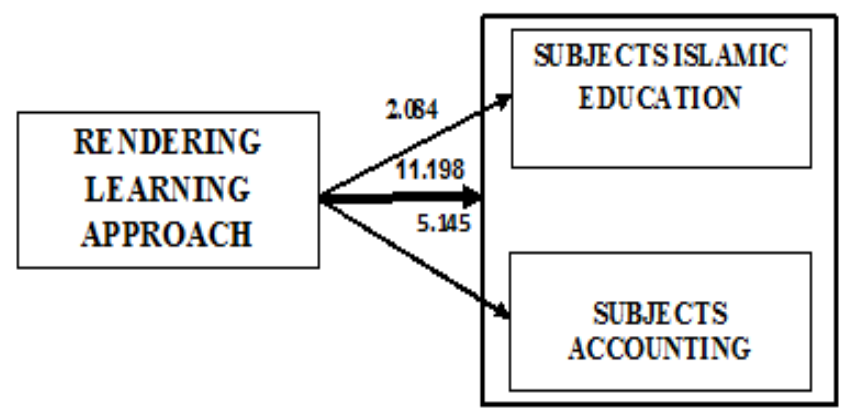

Fig.3 . Test Results the $t$ andAnova

\subsection{Rendering approach to subjects islamic education.}

Based on the results of test $t$ statistic model regression obtained value of the coefficients $\mathrm{X}_{1} 0.996$ or amounting to $99,6 \%$ so research showed that the approach rendering impact on subjects islamiceducation. This is proven by the acquisition value significance of 0.42 \&gt; 0.05.This research in line with Hidayat andArifudin.2014 ( 2014 ), which showed that approach rendering impact on study results.

\subsection{Rendering approach on subjects accounting education.}

Based on the results of the model $\mathrm{t}$ statistic regression obtained the value of the coefficient $\mathrm{X}_{2}$ as much as 0.50 or by $50 \%$ so that this research showed that rendering approach had an influence on subjects accounting education.This is proven by municipality significance as much as $0.00 \mathrm{\& gt} ; 0.05$ percentage point.Of this research was not in line with rahmadany and achadiyah (2017), which showed that the approach of rendering of its effect on learning outcomes.

\section{Conclusion}

a. Based on the model of $f$ analysis 11.198 obtained the significance of 0.000 \& it; 0.05 so regression significant so that it can be concluded that there are significant influence simultaneously variable subjects of islamiceducation and subject accounting education.

b. Based on the $t$ the results that there are three variable rendering partial approach in subjects islamic education influential amounting to 2.084 to the size of significant 0,042 $\&$ it; 0.05 , while variable approach in influential rendering partial amounting to 5.145 the significant $0,003 \&$ it; 0.05 on the subjects accounting education.

\section{Recommendation}

a. Next researchers can do research the like of hope can add variable subjects for islamic education with variable other like interest learning so as to can affect rendering approach more variable. 
b. Institutions should update information relating to education, especially in learning approach of applied so that islamic education subjects subjects and the accounting education can obtain easily understood and in doing.

c. The management is expected to could pay more attention of the application of a method of learning which he variative and reduce boredom.

d. Education institutions is expected to carry out one to make governance of teaching in which stakeholders interested to invest in education institutions.

\section{References}

[1] Kementrian Pendidikan dan Kebudayaan, "Permendikbud RI Nomor 65 Tahun 2013,” p. 3, 2013.

[2] Hosnan, "Pendekatan Saintifik dan Kontekstual dalam Pembelajaran Abad 21," Bogor Ghalia Indones., 2014.

[3] R. A. Sani, Pembelajaran Saintek Untuk Implementasi Kurikulum 2013. 2014.

[4] B. R. Joyce, M. Weil, and E. Calhoun, Models of Teaching, 5th Edition. 1996.

[5] T. ibnu badar Al-Tabany, "Mendesain Model Pembelajaran Inovatif, Progresif, dan Kontekstual," in PRENADAMEDIA GROUP, 2014.

[6] S. Nurohman, "Pendekatan Project Based Learning Sebagai Upaya Internalisasi Scientific Method Bagi Mahasiswa Calon Guru Fisika," 2007.

[7] J. Amernic and R. Craig, "Teform of accounting education in the post-enron Era: Moving accounting "out of the shadows," Abacus, 2004.

[8] Supriyono, Akuntansi Manajemen 1. 2001. 